\title{
Education for sustainability in business schools by practicing social learning
}

\author{
Paola Schmitt Figueiró ${ }^{*}$, Bruno Anicet Bittencourt ${ }^{2}$ and Soraia Schutel ${ }^{3}$
}

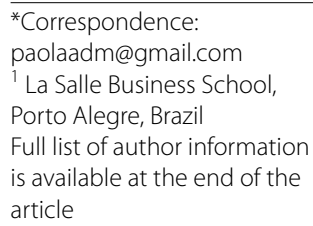

\begin{abstract}
The insertion of sustainability in business schools has been more relevant in the last decades. One of the purposes of education for sustainability (EfS) is to develop individuals with knowledge and skills to make decisions based on their environmental, social and economic context, through reflection and critical thinking, so that students are oriented toward action and change. Therefore, this paper emphasizes the need of collaboration between different actors on the teaching and learning process through Social Learning, as a theoretical perspective that considers socializing and learning as inseparable processes. Thus, the question that has oriented this research is "how can Social Learning, focusing on collaboration between different actors, contribute to effective EfS in business schools?"To answer this question, action research was conducted with a social project developed in a public high school, with children in high social vulnerability conditions, considering their interactions with two business schools in southern Brazil, in undergraduate and MBA courses. Through the integration of different socioeconomic realities, it was possible to analyze the construction of knowledge on issues related to sustainability and the transformation of those involved in the process of teaching and learning.
\end{abstract}

Keywords: Education for sustainability, Social learning, Collaboration

\section{Background}

The paradigms of management still reinforce the mainstream modus operandi of organizations, where decision-making is limited, in particular, to economic factors, without considering an integral perspective of management and human beings. In general, it is still based on instrumental rationality, responding to the capitalist model that evaluates workers exclusively for their production of wealth.

From this perspective, Morin (2005) points out that the probabilities of the world's future are alarming, to the extent that humanity is driven by four main gears: science, technology, economy and search for profit. In this way, natural resources are pushed to their limits and the current paradigm of growth no longer brings benefits to humanity (Garrity 2012).

Challenging and changing the mainstream requires new questions. If the objective of management is the proper functioning of an organization, the pursuit of efficiency, one may wonder: efficiency for whom, for what purpose, why? Organizations are being evaluated not only for economic factors, but also from an environmental and social point

(c) 2016 Figueiró et al. This article is distributed under the terms of the Creative Commons Attribution 4.0 International License (http://creativecommons.org/licenses/by/4.0/), which permits unrestricted use, distribution, and reproduction in any medium, provided you give appropriate credit to the original author(s) and the source, provide a link to the Creative Commons license, and indicate if changes were made. 
of view (Chanlat 2006). There is a need to stimulate new values and rethink the role of organizations in society.

In this scenario, sustainable development and sustainability emerge as possibilities to rethink and question the model of development of several nations. Studies about future sustainable development (Meadows 2006; Norberg-Hodge 2006; Arnaud and Sekerka 2010) point to a more humanistic perspective whose values lead to a new way of management and decision-making, taking the individual as an agent of change.

For this purpose, education is considered to play a crucial role in the change of mental models and worldview, enabling the construction of a new paradigm of sustainability and management (Garrity 2012). Thus, associated with the growing recognition that the natural environment and society should be a legitimate concern of organizations (Stead and Stead 2010), and also with the great increase of academic publications in the area (Benn and Dunphy 2009), some movements are gaining strength and legitimizing the presence of the so-called Education for Sustainability (EfS) at different levels of education.

EfS is focused on educating individuals with the knowledge, skills and understanding required to make decisions on the basis of their environmental, social and economic implications (Sterling 2011). It is a learning approach based on reflection and critical thinking, on consensus-building and partnerships, and on the training of students in the direction of action and change (Sidiropoulos 2014).

Among the major movements that are giving greater importance and visibility to the theme in management education, some stand out: the creation, in 1991, of the "Organizations and the Natural Environment" (ONE) Division of the Academy of Management (AOM), the UN Decade of Education for Sustainable Development (2005-2014), in addition to the presence of the theme in Management Education and Development (MED), another division of the AOM.

These factors have been influencing the release of several programs, degrees and courses that integrate sustainability into the teaching of management. These initiatives have been documented and published, with several special calls in academic journals, papers and books (see, among others, Brunstein et al. 2014; Muff et al. 2013; Caeiro et al. 2013; Starik et al. 2010; Springett and Kearins 2005).

In practice, the processes of teaching and learning focused on EfS in management programs require shifting from a teacher-centered to a student-centered approach. However, according to Figueiró and Raufflet (2015), one of the challenges to introducing sustainability into management education is related to pedagogical approaches.

So, given the practical difficulties related to education for sustainability, beyond the essentially technical approach linked to the theme, this paper seeks to bring an example of how the implementation of the Social Learning Theory can stimulate changes in traditional patterns of teaching from the interaction and collaboration between different actors.

Thus, Social Learning has been shown to be a valuable pedagogical approach with different tactics, strategies and methods that business educators might mobilize to prepare future business leaders to take responsible and ethical actions with new values for a new type of management that may emerge.

This theoretical approach assumes that individuals learn by observing or interacting with their social context. The interaction between different interests and realities is 
the basis that guided data collection and analysis in this research in order to answer the question "how can Social Learning, focusing on collaboration between different actors, contribute to effective EfS in business schools?"

To answer this question, action research was conducted with a social project-Convexo School-that integrates different actors such as a public high school, with children in high social vulnerability conditions, private enterprises, the local community and two business schools in southern Brazil, in undergraduate and MBA courses.

The results were analyzed based on the Social Learning theory and on Muff et al. (2013), who proposed a new educational paradigm focused on collaboration. It is a new view for management education whose aim is to educate responsible leaders based on engagement at three levels: individual, organizational and social (Muff et al. 2013), as will be addressed in the literature review section.

The paper is organized into six sections. The first deals with "Education for sustainability and management education" section, followed by theoretical discussions on "Social Learning" section. The third and fourth sections show, respectively, the methodology and the discussion and "Analysis of results". The fifth section describes "Education for sustainability and social learning: the power of collaboration", followed by the "Final remarks".

\section{Education for sustainability and management education}

The theme sustainability associated with the processes of teaching and learning in the education of future leaders constitutes the basis of the discussions in this paper. However, the understanding of the theme sustainability is generally limited to the efficiency of resources and the technical issues involved in environmental protection. The balance between its global, social, cultural and ethical dimensions is often unknown (Richter and Schumacher 2011; Benn and Dunphy 2009).

Thus, EfS is focused precisely on empowering individuals with the knowledge, skills and understanding required to make decisions that consider their environmental, social and economic implications. It is an approach to learning based on reflection and critical thinking, on consensus-building and partnerships, and on the training of students in the direction of action and change (Sidiropoulos 2014).

It involves a new proposal of teaching and learning in order to overcome the shortage of professionals in the field of management that have a systemic view of the relationship between organization, society and the environment. One of the major goals is to develop socioemotional skills of future professionals in the area of management.

However, in spite of the importance of a new profile of leaders and a new teaching format, there are great challenges ahead. Many managers still believe that they do not have the necessary skills to make their organizations more sustainable (Fisher and Bonn 2011). In other words, traditional management education fails to prepare future managers to meet the challenges of leadership and the constant ethical, social, environmental and political dilemmas in a world that is increasingly complex and interconnected (Pless et al. 2011).

According to De Melo et al. (2014), discussing the topic sustainability in management programs should take into account a review of business models that are addressed exclusively to profit maximization. This change of status quo demands a radical withdrawal 
from current beliefs and ways to operate (Kurucz et al. 2013). However, reality shows that "one of the major problems in current business is the fact that few of the outdated 'models' are effectively or radically questioned" (Aktouf 2011, p. 29).

A new perspective on management education assumes a higher valuation of human aspects, new values and collaboration between different actors, allowing a systemic and integrated view of all the links that constitutes the core business. Toward a new model of management education, Muff et al. (2013) highlighted three roles of business management accountable to society and to individuals. (1) educating and developing globally responsible leaders; (2) enabling business organizations to serve the common good; and (3) engaging in the transformation of business and the economy.

Based on this view, the authors proposed a new educational paradigm based on collaboration. It is a new view for management education aiming to develop responsible leaders based on three different levels of engagement: individual (educating), organizational (enabling) and societal (engaging) (Muff et al. 2013). Figure 1 shows the relationship between these elements.

The role education involves transformative learning; issue-centered learning; reflective practice and fieldwork. Engaging is related to open access between academia and practice; faculty as public intellectuals; institutions as role models. Enabling involves research in service of society; supporting companies towards stewardship; and accompanying leaders in their transformation. Finally, collaboratory is the preferred place for stakeholders to meet; and collaborative action learning and research platforms.

In order for this proposal to be possible, the authors pointed to the need to create spaces where this new view can happen. They referred to a space of co-creation for resolution of relevant issues at local, regional and global level (Muff et al. 2013). It can be said that collaboration is based on a perspective of interaction between different actors and different realities, through which teachers and students can interact with government institutions, NGOs, research centers, companies, consumers, community and social organizations, and with other students and teachers of the educational institution. This social interaction is the essence of Social Learning, the theme of the next section.

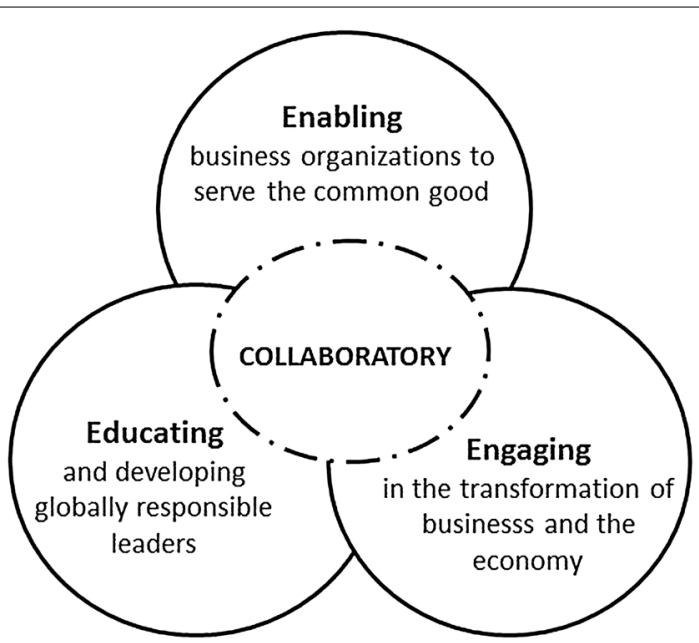

Fig. 1 The view of management education for the world. Source: Muff et al. (2013, p. 58) 


\section{Social learning}

Learning presupposes changes; however, individual learning and individual actions alone, although important, are not sufficient to redirect human activities on a global and local scale (Hansmann 2010). Collective action is required to coordinate interdependent efforts. In this way, the resulting collective learning can achieve new individuals (alone or in groups) and generate new behaviors. Social learning is an approach whose starting point is the daily experience that is lived, which considers socialization and learning as inseparable processes, because individuals are producers and products of the situations in which they are involved.

In the social learning system, new patterns of behavior can be acquired through direct experience or by observing the behavior of others (Bandura 1971). Bandura (1971), one of the most important theorists of human behavior from the twentieth century, believes that humans are active information processors and think about the relationship between their behavior and its consequences.

Therefore, the social perspective of learning shifts the focus of attention from information processing to the processes of interaction and participation that provide a real-life context for learning (Gherardi et al. 1998). In this perspective, learning can be considered as a continuous stream of social processes, which are the result of numerous connections and interactions between practitioners (Higgins and Mirza 2012).

Thus, the concept of social learning involves the learning of individuals through interaction or observation within their social context. It can be understood as a change in understanding, which goes beyond the individual and becomes situated within social units or communities of practice through interactions between actors within a social network (Reed et al. 2010).

What makes this perspective interesting to EfS, primarily, is the development of new capabilities of relationship between social agents, so that they can learn how to engage and understand the different roles and capacities of one another (Pahl-Wostl et al. 2008). Thus, "the interest in social learning from the perspective of sustainability is centered on understanding the power of social processes to instigate people to collaborate, share ideas, build common understandings and promote positive changes" (De Melo and Godoy 2014, p. 27). In other words, the power of collectivities can boost individual action, the development of socioemotional skills, and the construction of a more critical view in students, based on social practices that take into account experience sharing, interaction and collaboration.

For such intent, cooperation has to be promoted between individuals, because when people are gathered in groups, the construction of a consensus and mutual learning are effective means to deal with conflicting interests in a cooperative manner and toward sustainability (Hansmann 2010). In this context, it is incorrect to suggest that students have access to knowledge and action only in formal spaces of learning. Students develop their points of view, their attitudes and approach to the subject by means of interaction with their family, social groups, school activities, media, etc. (Reid et al. 2009).

Given the above, it is clear that Social Learning is in line with the assumptions of EfS, since they are both in pursuit of "development" beyond the individual and are focused on the context where people are involved, indicating collaboration as a way to promote change. Moreover, in the teaching and learning processes in the field of management, 
there is a need for greater coordination among different groups, arousing more humanistic experiences and perceptions that can strengthen the critical perspective and reflection about the role that business managers play in society.

Thus, this research was developed based on the interaction between Social Learning and EfS in a scenario that combines elementary education, higher education, graduate education, collaborative practices and management, as will be explained in the next section.

\section{Method}

In order to answer the research question, participatory action research was used as a method, since it assumes the implementation of a transforming action (Kemmis and McTaggart 2007). In this method, there is no separation between subject and object, because respondents are also subject of the research and participate in its construction collaboratively. In addition, it combines theory and practice, because it takes the theory to the field and then performs an action together with respondents (Brandão 1984; Kemmis and McTaggart 2007; Thiollent 2003).

The aspects of education and social transformation are also present, because all those involved in the research learn together; moreover, there is the emancipatory character: once respondents are aware of their situation, they may start to act more critically toward the environment where they are situated (Kemmis and McTaggart 2007).

In addition, participatory action research has a strong social commitment of the researcher, who is deeply involved in the research topic and acts in accordance with the values that he shares with respondents (Brandão 1984). This means that the researcher has a desire to make his research accessible to the public that is participating in it. Also, he wishes to put his scientific curiosity at the service of a social benefit to the community (Brandão 1982).

It should be noted that the participatory action research follows a very flexible planning strategy and data collection because the steps are being built during the research. One can say that it is an organic process in which analytical categories emerge over the achievement of the proposed interactions. Thus, no steps were pre-defined by researchers, but appeared as a consequence of one another.

In this context, two Interactions as part of a teaching episode were carried out involving collaboration between students from the field of management and elementary school students in a disadvantaged community in southern Brazil that were members of a social project-Convexo School-that aims to stimulate leadership by intertwining different realities.

The social project has been developed over the last 2 years, once-weekly, in a public school located in the outskirts of Porto Alegre, south of Brazil. It aims to solve local problems by empowering students aged between 7 and 17 years old through the development of entrepreneurship, communication and logical thinking skills. In this process, fifty students participate in Convexo School besides involving teachers, principals, parents and the whole community, as well as mentors and other people who provide funds and support the project financially and affectively.

Students at Convexo School choose a real problem in their school or community and learn to investigate and take decisions by defining ways and building new concepts to 
solve it. The methodology is supported by three pillars: communication, logics and entrepreneurship. Students improve their educational levels since they learn contents in Portuguese and Mathematics based on their everyday activities and life.

Besides, the Convexo's methodology is carried out according to four movements: the identification of a problem, its transformation into an opportunity, building a project and the development of businesses. Inside the classroom, students are divided into five thematic groups according to their competences: creativity, welfare, sustainability, technology and network.

In this paper, Interaction 1 occurred with the participation of undergraduate students from Learning to Learn discipline of a Management course (Unisinos University) and Interaction 2, with MBA students from Socioenvironmental Responsibility course (La Salle Business School). In both cases, based on problem-solving activities, the management students interacted with the other students-children and adolescents, aged between seven to 17 years old-and with other actors involved in the process, e.g., school principals and students' parents.

Convexo School was chosen because it is an educational initiative that involves the school community in the learning process, wherein the teaching and learning process happens through the resolution of problems in the region where the school is located. The groups of undergraduate students (Interaction 1) and MBA students (Interaction 2) were chosen because they are attending classes in the field of management, and also because the degree programs of these higher education institutions are open to projects that promote innovation in education. In addition, one of the authors of this paper is the social entrepreneur founder of Convexo School and the other authors teach the abovementioned courses, which facilitated the process of planning, implementing and monitoring the activities.

The intent of the present research was, therefore, to shed light on the collaboration between different actors in teaching and learning processes through Social Learning and its contribution to effective EfS in business schools, as will be further explained in this section and also in the analysis of results.

\section{Data collection}

The method of data collection was based on the active participation of researchers throughout the process. Unlike other methods, the authors of this research assumed the role of connectors, articulating the difficult rapprochement between different groups, from different social realities, and planning jointly activities. Thus, the authors actively operate throughout the research process, contributing to the achievement of each step.

Besides, testimonies of ten different actors involved in the project were used, as well as secondary data. The management students of Interaction 1 prepared a report containing their personal opinions and learnings during the experience. Students and teacher of Interaction 2 held a discussion group on the experience in the next class after the interaction. Besides, the researches used a block research notes while collecting data.

The research took place between April to July 2015. Interaction 1 was conducted on May 8th, 2015 and lasted for 6 h. Interaction 2 was carried out on June 26th, 2015 and lasted for $3 \mathrm{~h}$. However, there was a planning and previous preparation that lasted about 4 months before the day of interaction. 
Data analysis was based on group discussion sessions among researchers, associated with the crossing of the data from the testimonies and secondary data. The steps of this research followed the proposal of Kemmis and McTaggart (2007): Plan; Act and Observe; Reflect. Plan refers to the collection of all the necessary data and the subsequent planning of the action that will be performed.

Act and Observe refer to the moment of the action itself, which must be carefully performed in order to produce a great deal of data that will serve as food for thought. Reflecting with respondents on the action performed is aimed to understand what has emerged from the action and, if necessary, to provide input for planning a new action. Finally, the analysis of the information, as already mentioned, was based on the Social Learning theory and the model proposed by Muff et al. (2013).

The next section provides a description and analysis of the results while following the steps mentioned above.

\section{Description and analysis of results}

In this section the results will be described and analyzed based on the steps mentioned above in the method (Planning; Act and Observe; Reflection).

First, the planning step consisted in the organization that precedes the implementation of each Interaction. In 2015, students from Convexo School identified in the community where they live a relevant problem with women's unemployment and their lack of income. This problem was identified after the students interviewed 91 women who live in the community. The opportunity arose with one of the mentors who owns a vegan restaurant and is a member of a vegan and vegetarian restaurant chain in Porto Alegre: the possibility to create a cooperative which could aromatize olive oil to be sold to restaurants.

Therefore, this project became the focus of the work carried out by Convexo School, since students began to build the framework of this cooperative and to involve mothers and other community dwellers. The main goal is to make the cooperative generate the minimum wage to twenty women who participate in the project. A need emerged in this scenario to involve people from different realities in order to build a collaborative solution to solve a specific real problem.

Thus, given the need to establish a cooperative aiming at generating income for women in the region, it was found that students should have knowledge of basic notions about financial education. Therefore, the opportunity of Interaction 1 arose with the class of management undergraduate students. The goal was that the management students should empower the students at Convexo School.

For this reason, a children financial education specialist was invited to help the undergraduate students (Interaction 1) on some topics that they should address in their activities. Subsequently, members of Convexo School met with management students to organize the day of interaction. On that occasion, the interaction activities were proposed by the undergraduate students, mainly playful activities containing basic contents of financial management, and were validated by Convexo School and the professor of the management course.

Interaction 2, in turn, emerged at a time when the students from Convexo School were already structuring the cooperative and the difficulties with the new venture began to be 
strategic ones. The challenge of planning the next steps for structuring the cooperative resulted in the fact that the MBA students were invited to offer consultancy in business development to the students from Convexo School, and also to the students' mothers, who were taking up the venture.

Planning this action occurred on the basis of preparatory meetings between students, mothers, and the owner of the vegan restaurant, who was a partner in the initiative. Thus, the main and possible difficulties in the process of structuring the business were considered, such as: production of the oil, scents of the oil, advertising of the product, and managing relationships between the people involved. In addition, the professor of the MBA program shared with her class a great deal of information and materials that supported the activity.

It's important to highlight that the planning step demonstrates that the method used does not accurately predict the triggering of each stage, given that the Interactions were being articulated according to the demands that were emerging. In other words, it can be said that there was no pre-established expectations because the search field and its contributions were emerging on each approach and interaction performed. The next item describes how each of the Interactions happened.

Second, the act and observe step involves the integration of different realities trough the participation of two business schools. Interaction 1, as previously mentioned, was performed with management undergraduate students from Unisinos University, who prepared activities for the children of Convexo School that were related to financial education, sustainability and consumption, advised by a specialist in financial education for children. Three activities using dynamics, recycling, rethinking about priorities and consumption were developed with more than 120 children and integrated 30 undergraduate students, during 1 day at the school where Convexo School is located.

All participants were divided into three groups and allocated into two rooms to develop a set of activities that dealt with contents such as currency, importance and awareness of money, financial mathematics and sustainability. Right at the beginning, there was clearly a great rapport between all the people involved, mainly because the undergraduate students prepared something that was meaningful to the children. In addition, at the free time between the planned activities, there was a moment of socialization where everyone practiced sports together, which increased interaction, even though they belonged to very different social classes.

The second Interaction was carried out with students from the MBA program at La Salle Business School, who participated in online activities with the children and their mothers. The group of students, through a practical activity, was divided into work groups to assist in the creation of the cooperative. The purpose of this activity was to think of business development. There was a type of consultancy on the structure that was required to manufacture the products, including materials and the necessary partnerships, market and people that will work in this project.

First, everyone sat in a circle and introduced themselves by briefly talking about their personal characteristics, thus fostering a greater connection among the participants. The children spoke about their involvement with Convexo School, and one of the mothers gave a touching testimony about the changes that the school has been promoting in her daughters' lives. 
Table 1 Dimensions of analysis

\begin{tabular}{|c|c|}
\hline Analysis dimensions & Description \\
\hline Participants predisposition of involvement & $\begin{array}{l}\text { In this dimension we seek to assess the interest and } \\
\text { engagement of stakeholders in participating in the } \\
\text { project }\end{array}$ \\
\hline Intensity of exchanges & $\begin{array}{l}\text { The degree and the quality of interactions between the } \\
\text { different stakeholders involved in the project }\end{array}$ \\
\hline Openness and support of educational institutions & $\begin{array}{l}\text { At this dimension, we sought to verify if the educational } \\
\text { institution allowed the execution of the project and } \\
\text { its effective contribution }\end{array}$ \\
\hline $\begin{array}{l}\text { Involvement in the preparation of activities and their } \\
\text { conduction }\end{array}$ & $\begin{array}{l}\text { The dedication and commitment of stakeholders before } \\
\text { and during the interaction, how they reacted and } \\
\text { became protagonists in the process }\end{array}$ \\
\hline Promoted interactions and exchanges & $\begin{array}{l}\text { It is related to how much the stakeholders shared and } \\
\text { learned through interaction between them }\end{array}$ \\
\hline Nature/origin of the actors involved & $\begin{array}{l}\text { The heterogeneity of the actors who participated in the } \\
\text { project }\end{array}$ \\
\hline
\end{tabular}

After that, a challenge was posed: it consisted of a playful activity, a kind of board on which each step involved a different aspect of the planning and creation of the cooperative. The idea was that the MBA students should provide advice in each step. For this purpose, they were divided according to their abilities in different areas (production, people management and marketing).

The collective exchange of ideas was very intense, and brought together different views on the same theme. Another very important aspect was the active participation of one of the mothers, who gave valuable contributions by providing essential information to the processes. The fact that this mother helped and interacted made her feel more valued and "empowered".

Although the participants were divided into different fields for the resolution of various problems, there was clearly a high sense of teamwork. At particular moments, there was interaction between members of different groups. At the end, each group presented their solutions and sought solutions together. The next topic describes the reflection generated from the Interactions carried out.

In this second step, associated with the literature used, emerged dimensions of analysis that were used as conductors in the next sections of this paper. These categories are related to the involvement and participation of different stakeholders and theirs exchanges and interactions. The Table 1 illustrates the dimensions of analysis and their descriptions.

Finally, the third step-Reflection. The interaction and partnership between Convexo School and the business schools enabled the development of students' socio-emotional skills, e.g., empathy, collaboration, conscientiousness, respect for each other, learning to accept diversity. When students become acquainted with reality, while conducted by social learning, it is possible to stimulate the change of their worldview and the development of future managers that are aware of new ways and a new logic of doing business.

Moreover, through the integration of different socioeconomic realities, one can analyze the construction of knowledge on issues related to sustainability, sensitize business students to social responsibility, expand world view and foster the transformation of those involved in the process of teaching and learning. 
Making students from Convexo School and their mothers interact with students from business schools enabled them to develop a more entrepreneurial view regarding the cooperative, since they could see possibilities of improvement in the financial, commercial and operational areas. Besides, the experience encouraged the people involved in the business because they felt they had real support. Table 2 shows excerpts of some of the testimonies.

In general, one of the main reactions was that the management students were surprised to realize that while they began their participation in the activities aiming exclusively to help the children and their mothers. The contact with a socioeconomic reality so different from their own promoted reflection among all the people involved.

Another point that should be highlighted was the fact that the business students realized that they were also learning while teaching. This was an important lesson to the class of the first Interaction, especially taking into account that the teaching and learning process should be meaningful. In this case, all of the topics covered in both Interactions were part of the context where the children, the young people and their mothers lived, which awakened even more their interest in learning.

In general, the empowerment generated by the activities happened to all the people involved. The reports showed that everyone felt important with the presence of one another. They all clearly felt as participants in a process of major change, and saw this action as a possibility of promoting changes in the social and educational spheres.

\section{Education for sustainability and social learning: the power of collaboration}

The question that guided this study was "how can Social Learning, focusing on collaboration between different actors, contribute to effective EfS in business schools?" Based on the theoretical basis of Social Learning associated with the new proposal for management education of Muff et al. (2013), it was assumed that the collaboration in social relations between different actors can contribute to the change in mainstream education in business schools and generate the desired learning when it comes to EfS.

Thus, on the basis of the experiences and interactions described throughout this paper, and based on the proposal of Muff et al. (2013) to a new view of management education for the world, a new visual configuration of inter-relations between different actors is proposed, whereby the collaboration is also the central axis, but this time in a spiral that represents a movement of interaction between those involved. Thus, the position that each actor occupies in the spiral is not static, and the level of approximations takes place in accordance with the main objective of each new initiative. Figure 2 shows the visual representation of the spiral.

It should be noted that other actors may be involved in the processes of interaction and collaboration. However, the spiral proposed here is based on the relations identified in the two Interactions described in this paper. The intention was, therefore, to draw attention to collaboration as a central element for social learning, thus generating new perspectives for EfS in business schools. In other words, effective EfS requires social interaction and the integration of different interests, realities and experiences. In this case, encouraging the systemic and human view of management, as well as entrepreneurship, can take place as early as in basic education. 


\section{Table 2 Testimonies of respondents}

"It was an experience and a learning opportunity that I and my students are going to remember for the rest of our lives. An opportunity to consider people around us and reflect on life, but it's a reflection that allows you to move towards bigger dreams and transform people's lives"

"But the results went far beyond: an encounter of two worlds, where one learns from the other; a chance to challenge preconceptions, make the most of the opportunities that we have and, above all, a deep human connection and plenty of affection and gratitude. Having future managers get acquainted with reality enables reflections and personal changes that are necessary to build better business and improve Brazil. This is the type of education that I believe in and that makes sense to me"

"A few hours of intense work became seconds when we saw that the children, the young people and the parents were keen on using the management tools and highly motivated to change their reality. And the experience did not have such effect only on them, but also on me and certainly on many of my colleagues from the MBA program at Unilasalle"

"Sharing ideas and realities makes a difference and turns divergence into convergence, causing what is different to become unique and changing a difficult reality into an opportunity for effective change"

"We stepped out of our comfort zone, our reality, and we were able to experience a completely different reality and challenge our preconceptions. We thought that we were going to teach, but we ended up learning a lot, too. It is an exchange of experiences that I will remember for the rest of my life"

"This model allows the children to open up to learning, which does not happen only in the classroom, but also when these children interact with other people, with the world, on a daily basis. This increases their self-esteem and their desire for change"

"The changes are also perceived in their homes. My daughter is more closely connected with our family. She helps around the house more often. Her interaction with her classmates has also improved"

"Parents are more involved and are getting closer to their children. Given that it is a community that has stemmed from illegal occupation of land, the parents find it hard to be really involved in the school activities of their children. However, there was even a reduction in violence in the vicinity of the school"

"Escola Convexo can optimize the education of potential leaders, that is, it aims to develop leaders. In addition, it aims "to bring together and connect things and people, and each one connects in the way that they like better". In this sense, the school plays a role not only in developing the children and positively impacting the community, but also in integrating society with this reality, and promoting benefits that can be generated to mentors because they are part of this change"

"Some people came over on Saturday to help the Cooperative. We told them about Escola Convexo and after that we showed them data from the survey that we made in the community. We had a sort of a racing game on a board placed on the floor. We had to include the problems/obstacles that the cooperative may have to face. It was very nice, I love to meet new people and enjoy being at Convexo"

"We were visited by a group of people from a university. One of the activities was about recycling second-hand clothes. We had to make sketches and cuts on the garment to exercise our creativity. After we had finished, we had to present what we had done, what we used and how we did it"
Professor at UnilaSalle

Professor at Unisinos

Graduate student

Undergraduate student

Teacher from Escola Convexo

Mother of a student from Escola Convexo

School Principal

Student from Escola Convexo

Student from Escola Convexo 


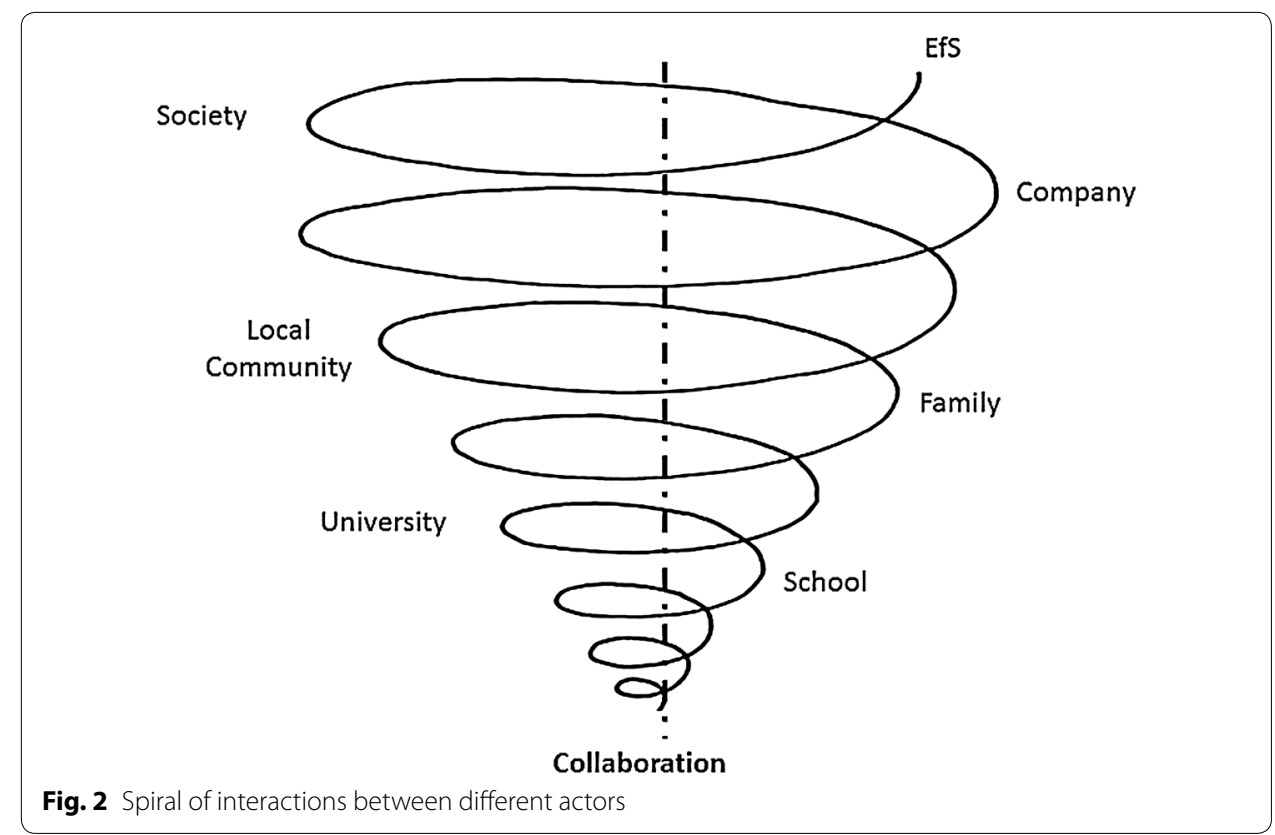

Social interactions occurred as a result of the involvement of different actors, such as elementary education students that attend Convexo School, their families, the school principals, local community where the school is located, entrepreneurs, higher education institutions with degree programs in the area of management. It is clear, therefore, that the involvement of different actors in processes of social interaction can generate learning for all the people involved. A feeling of belonging was noticed in different contexts and social realities, demonstrating a capacity for empathy that is not usually observed in traditional teaching environments.

In addition, there was also a clear sense of pride, especially from the management students, to participate in an activity in which they can exercise leadership roles, coordinate groups and prepare the activities that were planned without any type of attempt to control, thus enabling the management of autonomy in favor of the common good. It became apparent that the exchange of knowledge, which replaced the passive transmission of knowledge, provided each participant with the opportunity to contribute with what they know, and to develop socio-emotional skills that are better developed and sharpened from experiences outside the walls of a traditional classroom.

Finally, it's possible to verify that the theory of social learning is closely related to the theme of EfS, since the interactions and collaborations of different stakeholders are part of the construction of knowledge process. EfS requires a broader view on economic and environmental issues that can be reinforced from living experiences and exchanges. Therefore, this article strengthens the collaboration as an essential factor of EfS.

\section{Final remarks}

In this paper a participatory action research was held to answer the question "how can Social Learning, focusing on collaboration between different actors, contribute to effective EfS in business schools?" The chosen method has also an educational and social 
transformation character, because all the participants involved in the research learned together.

We used the steps suggested by Kemmis and McTaggart (2007)-Planning, Act and Observe, Reflection-beyond the proposal of Muff et al. (2013) for the analysis of the results, considering that the interactions described here include the three fundamental roles in management education: educating, enabling and engaging.

Realizing that education is essential for a future sustainable development and that management should rethink its role in this process, two Interactions were accomplished in which students of business schools had to interact with students from different realities in order to build a collective welfare. The meetings were made possible due to the opening and encouragement offered by educational institutions where teachers and researchers act, as well as the availability and interest of Convexo School whose essence is to bring together different worlds and generate transformation in people by solving problems.

The main contribution of the research was to demonstrate the relevance of the interaction between different actors in the processes of teaching and learning. It is clear the importance of teaching and learning environments on encouraging the rapprochement between different social contexts and the practice of collaboration. From these experiences it's possible to emancipate the human side, with exchanges of knowledge and affection.

It was possible to notice how social learning can contribute to an effective EfS, whose experience and mutual assistance help in the development of socio-emotional skills that has a great importance for decision-making in the management focused on sustainability. It was found that the importance of this experience is not the participation of a particular individual, but rather the power of the collective, of a spiral centered on collaboration.

In addition, from this research it is possible to perceive that EfS should not be related only to technical/environmental knowledge, which is usually related to the teaching of sustainability, but also to the socio-emotional knowledge that can be stimulated from the interaction between different realities. Thus, sustainability could be inserted on the education of future managers with the purpose of providing experiences that awaken the ability to empathy, because in this way will be possible to have a holistic view on social, economic and environmental dimensions of sustainability.

Finally, this research has as contribution on the way it was conducted and provided interactions. The method, which involved researchers in the learning process, enabled that the research was built organically and collaboratively, not aiming to achieve predetermined goal. Besides, the Interactions provided with this study joined different worldviews and reiterates the importance of collective learning. Thus, the method used allows creating new worldviews in management students and enables them not only to develop empathy to other lives, but self-questioning: what can I do to improve this reality?

The main challenge of this research was to reconcile interests between actors who work in such different spheres. However, this approach and implementation of ideas becomes possible at the time when people have a common purpose. For future studies, we suggest the expansion of this research to other educational environments and the involvement of other actors, such as the government. It is believed that more the spiral 
involves and engages people, more effective will be the EfS, and therefore more sustainable and balanced will be the world where we live in.

\section{Authors' contributions}

PSF, BAB and SC carried out the "Education for sustainability in business schools by practicing social learning" study, participated in the sequence alignment and drafted the manuscript. All authors read and approved the final manuscript.

\section{Author details}

${ }^{1}$ La Salle Business School, Porto Alegre, Brazil. ${ }^{2}$ Federal University of Rio Grande do Sul, Porto Alegre, Brazil. ${ }^{3}$ Unisinos University, São Leopoldo, Brazil.

\section{Competing interests}

The authors declare that they have no competing interests.

Received: 4 October 2015 Accepted: 25 February 2016

Published online: 22 March 2016

\section{References}

Aktouf O (2011) A Administração entre a tradição e a renovação. São Paulo, Atlas

Arnaud A, Sekerka LE (2010) Positively ethical: the establishment of innovation in support of sustainability. Int J Sustain Strateg Manag 2(2):121-137

Bandura A (1971) Social learning theory. General Learning Press, New York, p 46

Benn S, Dunphy D (2009) Action research as an approach to integrating sustainability into MBA programs: an exploratory study. J Manag Educ 33(3):276-295

Brandão CR (1982) Pesquisa Participante. São Paulo, Brasiliense

Brandão CR (1984) Repensando a Pesquisa Participante. São Paulo, Brasiliense

Brunstein J, Godoy AS, Silva HC (eds) (2014) Educação para Sustentabilidade nas Escolas de Administração. São Carlos, RiMa Editora, p 384

Caeiro S et al (eds) (2013) Sustainability assessment tools in higher education institutions: mapping trends and good practices around the world. Springer International Publishing, Switzerland, p 432

Chanlat JF (2006) Ciências sociais e management. Revista de Administração da FEAD-Minas 3(2):9-17

De Melo AS, Godoy AS (2014) Integrando o conceito de aprendizagem social pelas perspectivas da sustentabilidade e da aprendizagem organizacional. Cap. 3. In: Brunstein J, Godoy AS, Silva HC (eds) Educação para Sustentabilidade nas Escolas de Administração. RiMa Editora, São Carlos

De Melo EC, Brunstein J, Godoy AS (2014) Experiências docentes em educação para a sustentabilidade em escolas de negócios: uma análise à luz dos conceitos de reflexão crítica e aprendizagem transformadora. Cap. 10. In: Brunstein J, Godoy AS, Silva HC (eds) Educação para Sustentabilidade nas Escolas de Administração. RiMa Editora, São Carlos

Figueiró PS, Raufflet E (2015) Sustainability in higher education: a systematic review with focus on management education. J Clean Prod 106:22-33

Fisher J, Bonn I (2011) Business sustainability and undergraduate management education: an Australian study. High Educ 62:563-571

Garrity EJ (2012) Tragedy of the commons, business growth and the fundamental sustainability problem. Sustainability 4:2443-2471

Gherardi S, Nicolini D, Odella F (1998) Towards a social understanding of how people learn in organizations. The notion of a situated curriculum. Manag Learn 29:273-297

Hansmann R (2010) "Sustainability learning": an introduction to the concept and its motivational aspects. Sustainability 2:2873-2897

Higgins D, Mirza M (2012) Considering practice: a contemporary theoretical position towards social learning in the small firm. Irish J Manag 31(2):1

Kemmis S, McTaggart R (2007) Participatory action research. In: Denzin NK, Lincoln Y (eds) Handbook of qualitative research. Sage Publications, London

Kurucz EC, Colbert BA, Marcus J (2013) Sustainability as a provocation to rethink management education: building a progressive educative practice. Manag Learn 45(4):437-457

Meadows DL (2006) Tools for the transition to sustainability. In: Keiner M (ed) The future of sustainability. Springer, Netherlands, pp 161-178

Morin E (2005) Restricted complexity, general complexity. proceedings of colloquium "Intelligence de la complexité: épistémologie et pragmatique", Cerisy-La-Salle, France

Muff K et al (2013) Management education for the World: a vision for business schools serving people and planet. Edward Elgar Publishing, EUA p $23 \mathbf{2}$

Norberg-Hodge H (2006) Sustainable economies_local or global? In: Keiner M (ed) The future of sustainability. Springer, Netherlands, pp 99-115

Pahl-Wostl C, Mostert E, Tàbara D (2008) The growing importance of social learning in water resources management and sustainability science. Ecol, Soc $\mathbf{1 3}$

Pless NM, MaakT, Stahl GK (2011) Developing responsible global leaders through international service-learning programs: the Ulysses experience. Acad Manag Learn Educ 10(2):237-260

Reed MS et al (2010) What is social learning?. Ecol, Soc 15

Reid A, Petocz P, Taylor P (2009) Business Students' conceptions of sustainability. Sustainability 1:662-673 
Richter T, Schumacher KP (2011) Who really cares about higher education for sustainable development? J Soc Sci 7(1):24-32

Sidiropoulos E (2014) Education for sustainability in business education programs: a question of value. J Clean Prod 85:472-487

Springett D, Kearins K (2005) Special issue: educating for sustainability—an imperative for action. Bus Strategy Environ 14(3):143-145

Starik M et al (2010) Special issue on sustainability in management education. Acad Manag Learn Educ 9(3):377-383

Stead JG, Stead WE (2010) Sustainability comes to management education and research: a story of coevolution. Acad Manag Learn Educ 9(3):488-498

Sterling S (2011) Transformative learning and sustainability: sketching the conceptual ground. Learn Teach High Educ 5:17-33

Thiollent M (2003) Metodologia da Pesquisa-Ação. São Paulo, Cortez

Submit your manuscript to a SpringerOpen ${ }^{\circ}$ journal and benefit from:

- Convenient online submission

- Rigorous peer review

- Immediate publication on acceptance

- Open access: articles freely available online

- High visibility within the field

- Retaining the copyright to your article

Submit your next manuscript at $\boldsymbol{\nabla}$ springeropen.com 